\title{
Evaluation of variation of D-dimer levels in COVID-19 patients to predict the disease outcome in a hospital based study
}

\author{
Shahtaj Khan', Hamzullah khan², Saba khan ${ }^{3}$, Mansoor Akhtar ${ }^{4}$ \\ 1. Professor \& Head, Department of Hematology Hayatabad Medical Complex, Peshawar \& Chairperson Provincial Passive \\ Immunization Committee for use of plasma from convalescent COVID-19 positive patients. Peshawar, Pakistan. \\ 2. Associate Professor Hematology, Director Research and Development, Nowshera Medical College, Nowshera, Pakistan \\ 3. Trainee Medical Officer, Hayatabad Medical Complex, Peshawar, Pakistan \\ 4. Medical Officer \& Anesthetist, Health Department, Khyber Pukhtoonkhwa
}

Correspondence: Hamzullah Khan, Associate Professor Hematology, Director Research and Development, Nowshera Medical College, Kabul River Mardan Road,Nowshera-25000, Pakistan; E-mail: hamzakmc@gmail.com; Phone: 0334-4802902

\section{Abstract}

Objectives: D-dimers is a sensitive indicator in COVID-19 patients. We aimed to determine the contribution of demographic factors (age and gender) toward an elevated d-dimer values, and to determine the probability of surviving in different age groups in COVID-19, with d-dimer $>0.5 \mu \mathrm{g} / \mathrm{ml}$.

Methodology: A total of 193 patients were enrolled from COVID-19 isolation units of Hayatabad Medical Complex Peshawar, whose d-dimer levels were performed as per instructions of the treating physician and were followed. Relevant information's were recorded on a pre-designed performa prepared in accordance with the objectives of the study.

Results: Out of total 193 patients 152 (78.8\%) were males and 41 (21.2\%) females. 94(48.7\%) patients were in the age range $35-55$ y while $76(39.4 \%)$ patients had age more than 55 y. Regarding d-dimer readings, 162 (83.9\%) had d-dimer levels more than $0.5 \mu \mathrm{g} / \mathrm{ml}$. The mean with standard deviation of age of the patients was $52 \pm 13 \mathrm{yrs}$. The mean with standard deviation of d-dimer values of the patients was $4.9 \pm 13.3 \mu \mathrm{g} / \mathrm{ml}$. It was observed that, the relative risk of deranged values of $d$-dimers was $1.18(r r=1.18)$ in patients with age $>55$ yrs. Similarly, in female gender the relative risk of higher values of d-dimers above normal was $1.26(r r=1.26)$ without reaching a statistically significant $p$-value $(p=0.48)$. The probability of worse outcome in term of death was 2.06 times more in patients with d dimers $>0.5 \mu \mathrm{g} / \mathrm{ml}(O R=2.06)$. Furthermore the probability of surviving was $90-100 \%$ by age $\leq 50 \mathrm{y}, 80 \%$ in age range $51-60 \mathrm{y}, 45 \%$ in age range $61-70 \mathrm{y}$ and $30 \%$ at age $\geq 80 \mathrm{y}$.

Conclusion: The deranged d-dimer levels were noted in $84 \%$ of the COVID-19 patients. Age $>55$ y and female gender are at higher risk of deranged d-dimers and further consequences. Survival rate of patients with deranged d-dimers drops to $30 \%$ in patients with age $\geq 80 \mathrm{y}, 45 \%$ at age $\leq 70 \mathrm{y}$.

Key word: COVID-19, D-dimers, survival rate, prognostic values

Citation: Khan S, Khan H, Khan S, Akhtar M. Evaluation of variation of D-dimer levels in COVID-19 patients to predict the disease outcome in a hospital based study. Anaesth. pain intensive care 2020;24(5):490-496

Received: 20 June 2020, Reviewed: 24, 28 June 2020, Accepted: 1 July 2020

\section{Introduction}

COVID-19 is pandemic respiratory infectious disease with unknown etiology, was first reported to the WHO office on $31^{\text {st }}$ Dec 2019, from Wuhan, a metropolitan city in the province of Hubei China. ${ }^{1}$ Case fatality rate of $2.3 \%$ has been reported from china that is lower than SARS $(9.5 \%)$, MERS $(34.4 \%)$ and H7N9 (39\%). ${ }^{2}$ 
Regarding the transmissibility of the COVID-19, the basic reproductive number (R0), which is a measure of the expected number of cases generated from one positive case, is 1.5-3 for SARS-CoV, compared to 1.5-5 for MERS-CoV. ${ }^{3}$ The majority of the infected cases are asymptomatic. However, $20 \%$ of the cases develop viral pneumonia characterized by fever, cough shortness of breath, and acute lung injury, with an overall mortality rate of $2.3 \% .^{4}$

Since the early epidemic, the scientist suggested that the COVID-19 may directly has an impact on the cardiovascular system, either by increasing the mortality specially in patient with cardiac manifestations of COVID-19 has some association with cardiovascular complication most importantly causing venous throboembolism. ${ }^{5}$

Potentially the linkage of COVID-19 and venous thromboembolism is well described and reported by number of authors with significant alteration of the hematological parameters in corona infection. Some have described the association of these hematological abnormalities with an increase in the level of d-dimers in COVID-19. ${ }^{6,7,8}$

D-dimer on admission greater than $2.0 \mu \mathrm{g} / \mathrm{mL}$ (fourfold increase) could effectively predict in-hospital mortality in patients with Covid-19, which indicated D-dimer could be an early and helpful marker to improve management of Covid-19 patients. $^{9}$

$\mathrm{Yu} \mathrm{B}$ et al reported from China that there was a fold increase in hospital mortality associated with an increasing d-dimers level more than $1 \mu \mathrm{g} / \mathrm{mL}$ at time of admission. ${ }^{10}$

Present study was therefore designed with the objectives to,

1. Determine the variation of d-dimers in COVID-19.

2. Determine the contribution of demographic factors (age and gender) toward elevated d-dimers values.

3. Determine the probability of surviving in different age groups in COVID-19, with d-dimer $>0.5$ $\mu \mathrm{g} / \mathrm{ml}$ in a hospital based study.

\section{Methodology}

This cross-sectional study was conducted from $8^{\text {th }}$ may to $2^{\text {nd }}$ June 2020 in a tertiary care hospital of Peshawar. A total of 193 COVID-19 patients were included.

\subsection{Population \& Sampling}

Assuming 4\% prevalence of COVID-19 in general population from the study of Zhou $\mathrm{X}$ et al; 8 a reference population of 100,000 patients was estimated to reside in the catchment area of our teaching hospital, Hayatabad Medical Complex Peshawar, Khyber Pakhtunkhwa, Pakistan. A sample size of 193 was calculated through Open-epi software, an online sample size calculator, with Absolute precision of 5\%, confidence interval of $95 \%$, and a drop out of $10 \%$.

Only patients hospitalized with COVID-19 in isolation unit of HMC were included. Only covid-19 patients where d-dimers were advised by the treating consultant were included irrespective of age and gender.

Similarly those patients were observed for disease outcome in terms of satisfactory discharge or case fatality due to COVID-19.

COVID-19 patients where d-dimers were not advised were excluded. Similarly all patients with any type of symptoms came to emergency or outdoor patients department or even confirmed patients of COVID-19 in isolation department where d-dimers were not advised were also excluded.

The samples for laboratory testing were collected under aseptic techniques using venous blood $3 \mathrm{ml}$ from hospitalized patients. D-dimer assays was performed with use of citrated, heparinized or EDTA plasma (Pathfast ${ }^{\circledR}$, Tina-quant ${ }^{\circledR}$ (Roche, technology). D-dimer test was conducted on COBAS-511 (Roche Diagnostics), using particle-enhanced immunoturbidimetric assay (Tina-quant ${ }^{\circledR}$ ). A value of $<0.5 \mu \mathrm{g} / \mathrm{ml}$ was taken as normal.

\subsection{Ethical endorsement}

Ethical endorsement was obtained from the institutional ethical review board of Post-Graduate Medical Institute, Hayatabad Medical Complex under notification No (316/HEC/B \& PSC/2020 Dated 15th May 2020).

Prior informed consent was obtained from all suspects and they were assured of confidentiality.

For COVID confirmation, PCR results of the nasopharyngeal swab duly reported in Public health research laboratory of the Hospital and also of the Khyber medical University (a designated Lab for PCR 
of $2019 \mathrm{nCoV}$ by the Government of Khyber Pukhtunkhwa) were considered only.

\subsection{Operational definitions}

Child: Article 1 of The United Nations Convention on the Rights of the Child defines a child as "for the purposes of the present Convention, a child means every human being below the age of $18 \mathrm{yr}$ unless under the law applicable to the child, majority is attained earlier". ${ }^{11}$

Adult: Young adult 19-35 yr, middle-aged adult 36-55 yr and older adult $>56$ yr. $^{12}$

\subsection{Data analysis}

Data was entered in SPSS $25^{\text {th }}$ version and descriptive and correlation statistics were applied. Numerical variables like age of patients and d-dimer values were presented as Mean with standard deviation and range.

Correlation tests using spearman ranked correlation was used to determine the correlation of d-dimers with age and gender categories and disease outcome.

Chi-square test was used to show a relationship of the elevated d-dimers with age categories, gender groups and disease outcome in COVID-19 patients.

Relative risk analysis was done for risk estimation in age and gender groups and for case fatality with elevated d-dimers levels.

Kaplan Meir test was used for survival analysis to compare the mortality rate in COVID-19 patients under the influence of the elevated d-dimers levels

\section{Results}

The mean with standard deviation of age of the patients was $52 \pm 13 \mathrm{yr}$. A minimum of $10 \mathrm{y}$ with a maximum of $80 \mathrm{y}$ of age was recorded with age range of $70 \mathrm{y}$. Mode of age was $55 \mathrm{yr}$. The mean with standard deviation of d-dimer values of the patients was $4.9 \pm 13.3 \mu \mathrm{g} / \mathrm{ml}$. The minimum of the recorded values was 0.04 to a maximum of $109 \mu \mathrm{g} / \mathrm{ml}$. (Table 1)

Out of total 193 patients 152 (78.8\%) were males and $41(21.2 \%)$ females. $94(48.7 \%)$ patients were in the age range $35-55$ y while $76(39.4 \%)$ patients had age more than $55 \mathrm{y}$. Regarding d-dimer readings, 162 (83.9\%) had d-dimer levels more than $0.5 \mu \mathrm{g} / \mathrm{ml} .161$ $(83.4 \%)$ of the patients were discharged satisfactorily.
Table 1: Descriptive Statistics

\begin{tabular}{lc|c}
\multicolumn{1}{c}{ Value } & D-dimer & Age \\
\hline Number of patients & 193 & 193 \\
\hline Mean & 4.94 & 52 \\
\hline Median & 1.60 & 54 \\
\hline Mode & 0.70 & 55 \\
\hline Standard deviation & 13.50 & 13 \\
\hline Range & 109.00 & 70 \\
\hline Minimum & 0.04 & 10 \\
\hline Maximum & 109.00 & 80 \\
\hline
\end{tabular}

We observed patients in isolation only whose d-dimer was advised and hence the death rate here (32 cases out of 193) does not reflect the mortality rate as we did not follow all positive cases, we followed only the COVID-19 cases who were advised d-dimers by the treating physician (Table 2).

We observed a significant difference in the levels of ddimers in age groups. In patients with age $>55 \mathrm{yr}$ the relative risk of higher values of d-dimers above normal was $1.18(r r=1.18)$ without reaching a statistically significant $\mathrm{p}$-value $(p=0.47)$. The relative risk values

Table 2:

\begin{tabular}{lcc}
\hline \multicolumn{1}{c|}{ Variables } & Frequency & Percent \\
\hline \multicolumn{1}{c}{ 2.1. Gender } & \\
\hline Male & 152 & 78.8 \\
\hline Female & 41 & 21.2 \\
\hline Total & 193 & 100.0 \\
\hline \multicolumn{1}{c}{ 3.2. Age brackets } & \\
\hline$<18 \mathrm{yr}$ & 1 & 0.5 \\
\hline 19-35 yr & 22 & 11.4 \\
\hline 36-55 yr & 94 & 48.7 \\
\hline$>55 \mathrm{yr}$ & 76 & 39.4 \\
\hline Total & 193 & 100.0 \\
\hline 3.3. D-dimer categories & \\
\hline$<0.5 \mu \mathrm{g} / \mathrm{ml}$ & 31 & 16.1 \\
\hline$>0.5 \mu \mathrm{g} / \mathrm{ml}$ & 162 & 83.9 \\
\hline Total & 193 & 100.0 \\
\hline 3.4. Disease outcome & \\
\hline Discharged & 161 & 83.4 \\
\hline satisfactorily & 32 & 100.0 \\
\hline Died & 193 & \\
\hline Total & & \\
\hline
\end{tabular}


Table 3: Inferential statistics for significance, correlation and relative risk of d-dimer values in COVID-19

\begin{tabular}{|c|c|c|c|c|c|c|c|}
\hline \multirow{2}{*}{ D-dimer ( $\mu \mathrm{g} / \mathrm{ml})$} & \multicolumn{2}{|c|}{ Age categories } & \multirow{2}{*}{ Total } & \multirow{2}{*}{$\begin{array}{c}\text { Asymptotic } \\
\text { Significance (2- } \\
\text { sided)-Chi square } \\
\text { test }\end{array}$} & \multirow{2}{*}{$\begin{array}{l}\text { Odds } \\
\text { Ratio } \\
\text { (OR) }\end{array}$} & \multirow{2}{*}{ Relative risk (rr) } & \multirow{2}{*}{$\begin{array}{c}\text { Pearson } \\
\text { Correlation(r) }\end{array}$} \\
\hline & $<55$ y & $>55 \mathrm{y}$ & & & & & \\
\hline$<0.5$ & 17 & 14 & 31 & \multirow{3}{*}{$p=0.47$} & \multirow{3}{*}{0.8} & Age $>55 y=1.18$ & \multirow{3}{*}{0.06} \\
\hline$>0.5$ & 100 & 62 & 162 & & & Age $<55 y=0.8$ & \\
\hline Total & 117 & 76 & 193 & & & & \\
\hline \multicolumn{8}{|c|}{ 3.2. D-dimer values and gender factor in COVID-19 } \\
\hline \multirow[b]{2}{*}{ D-dimer ( $\mu \mathrm{g} / \mathrm{ml})$} & \multicolumn{2}{|c|}{ Gender } & \multirow[b]{2}{*}{ Total } & \multirow{2}{*}{$\begin{array}{c}\text { Asymptotic } \\
\text { Significance (2- } \\
\text { sided)-Chi square } \\
\text { test }\end{array}$} & \multirow{2}{*}{$\begin{array}{l}\text { Odds } \\
\text { Ratio } \\
\text { (OR) }\end{array}$} & \multirow[b]{2}{*}{ Relative risk } & \multirow{2}{*}{$\begin{array}{l}\text { Pearson } \\
\text { Correlation }\end{array}$} \\
\hline & Male & Female & & & & & \\
\hline$<0.5$ & 23 & 8 & 31 & \multirow{3}{*}{$p=0.48$} & \multirow{3}{*}{0.7} & Females $=1.26$ & \multirow{3}{*}{0.08} \\
\hline$>0.5$ & 129 & 33 & 162 & & & & \\
\hline Total & 152 & 41 & 193 & & & IVlales $=0.9$ & \\
\hline \multicolumn{8}{|c|}{ 3.3. D-dimer values and Disease Outcome in COVID-19 } \\
\hline \multirow[b]{2}{*}{ D-dimer $(\mu \mathrm{g} / \mathrm{ml})$} & \multicolumn{2}{|c|}{ Disease Outcome } & & \multirow{2}{*}{$\begin{array}{c}\text { Asymptotic } \\
\text { Significance (2- } \\
\text { sided)-Chi square } \\
\text { test }\end{array}$} & \multirow{2}{*}{$\begin{array}{l}\text { Odds } \\
\text { Ratio } \\
\text { (OR) }\end{array}$} & \multirow[b]{2}{*}{ Relative risk } & \multirow{2}{*}{$\begin{array}{l}\text { Pearson } \\
\text { Correlation }\end{array}$} \\
\hline & Satisfactory & Died & Total & & & & \\
\hline$<0.5$ & 28 & 3 & 31 & \multirow{3}{*}{$p=0.25$} & \multirow{3}{*}{2.06} & Died $=1.1$ & \multirow{3}{*}{0.08} \\
\hline$>0.5$ & 133 & 29 & 162 & & & Discharged & \\
\hline Total & 161 & 32 & 193 & & & $\begin{array}{l}\text { satistactorily = } \\
0.5\end{array}$ & \\
\hline
\end{tabular}

Table 4: Cross-tabulation of Dichotomous variables of age, d-dimer and disease outcome

\begin{tabular}{|c|c|c|c|c|c|c|}
\hline \multirow{2}{*}{\multicolumn{3}{|c|}{ Age as dichotomous variable }} & \multicolumn{2}{|c|}{ D-dimer categories } & \multirow{2}{*}{ Total } & \multirow{2}{*}{$\begin{array}{l}\text { Death rate in patient } \\
\text { with d-dimer }>0.5 \\
\mu \mathrm{g} / \mathrm{ml}\end{array}$} \\
\hline & & & $<0.4 \mu \mathrm{g} / \mathrm{ml}$ & $>0.4 \mu \mathrm{g} / \mathrm{ml}$ & & \\
\hline \multirow{3}{*}{$<55$ y } & \multirow{2}{*}{$\begin{array}{l}\text { Disease } \\
\text { outcome }\end{array}$} & Satisfactory & 16 & 86 & 102 & \multirow{3}{*}{$44 \%$} \\
\hline & & Died & 1 & 14 & 15 & \\
\hline & Total & & 17 & 100 & 117 & \\
\hline \multirow{3}{*}{$>55$ y } & \multirow{2}{*}{$\begin{array}{l}\text { Disease } \\
\text { outcome }\end{array}$} & Satisfactory & 12 & 47 & 59 & \multirow{3}{*}{$47 \%$} \\
\hline & & Died & 2 & 15 & 17 & \\
\hline & Total & & 14 & 62 & 76 & \\
\hline \multirow{3}{*}{ Total } & Disease & Satisfactory & 28 & 133 & 161 & \multirow{3}{*}{ Overall 29/32 (91\%) } \\
\hline & outcome & Died & 3 & 29 & 32 & \\
\hline & Total & & 31 & 162 & 193 & \\
\hline
\end{tabular}

above 1 indicates age > $55 \mathrm{yr}$ as a risk factor in prognosis. When gender groups was analyzed for the d-dimer values we observed that in female gender the relative risk of higher values of d-dimers above normal was $1.18(r r=1.26)$ without reaching a statistically significant $\mathrm{p}$-value $(p=0.48)$. The relative risk values above 1 indicates gender as a risk factor in prognosis.
We observed that the probability of worse outcome in term of death was 2.06 times more in patients with ddimers $>0.5 \mu \mathrm{g} / \mathrm{ml}(O R=2.06)$ with a relative risk of 1.1. (Table 3). It was noted that in patients with age < (14/32) $44 \%$ of $55 \mathrm{yr}$ and d-dimers $>0.5 \mu \mathrm{g} / \mathrm{ml}$ the death rate was the highest.

We used Kaplan Meir test to calculate the median survival in COVID-19 patients in present study under 
the influence of the d-dimer values. We observed that the probability of surviving was $90-100 \%$ by age $\leqq 50$ $\mathrm{yr}, 80 \%$ in age range $51-60 \mathrm{yr}, 45 \%$ in age range 61 -
$70 \mathrm{yr}$ and astonishingly the survival plot touched the line of $30 \%$ when the age of the patients was $80 \mathrm{yr}$ or more (Figure-1).

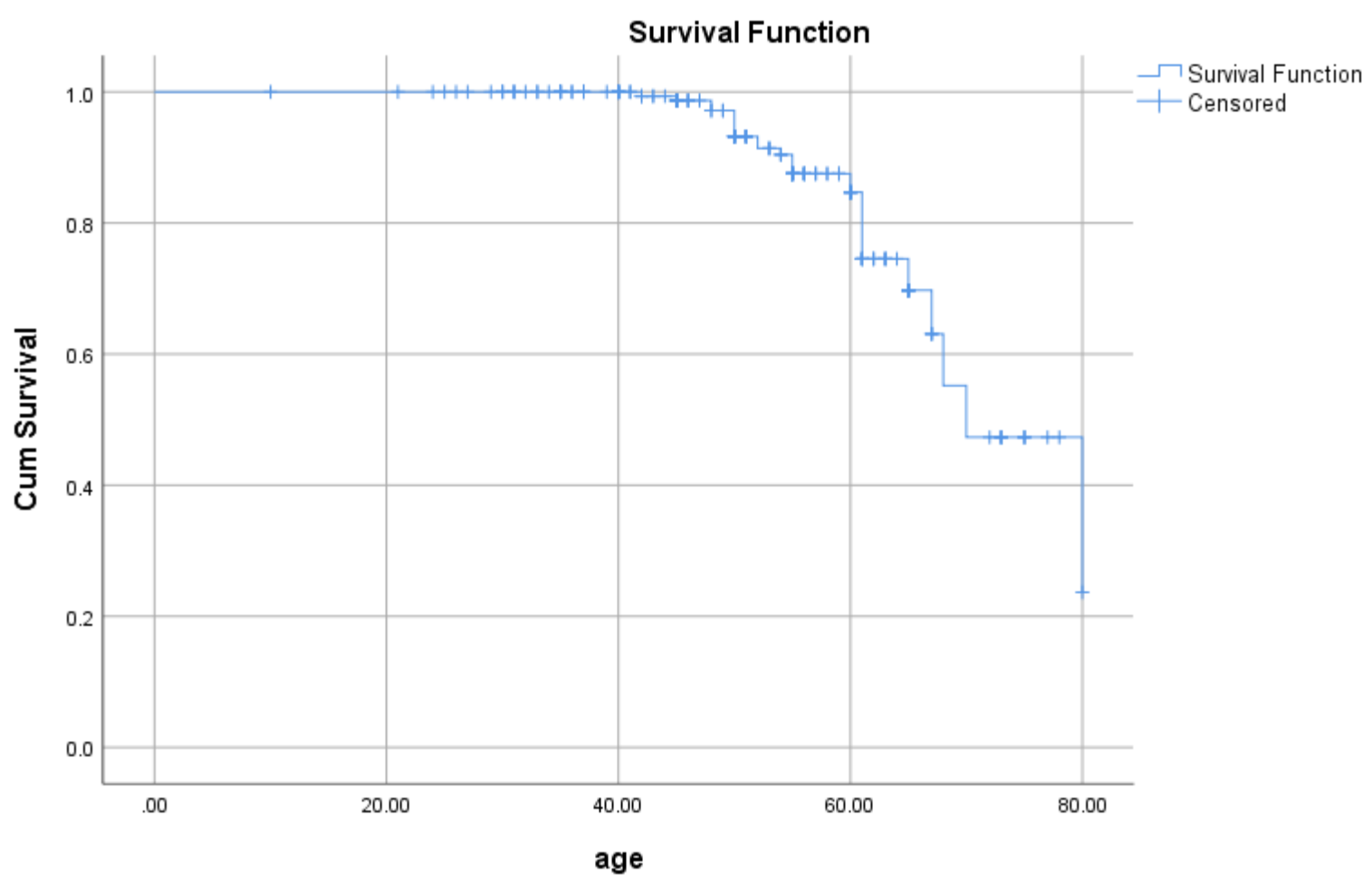

Figure 1: Survivability of COVID-19 patients plotted against age

\section{Discussion}

An elevated d-dimers in COVID-19 is the hallmark predictor of mortality and septic shock. ${ }^{13}$ The prominent feature of the COVID-19 is the coagulopathy and prothrombotic stage with homeostatic derangement representing the major clinic-pathological manifestation of this deadly disease. The severity of the abnormality in the coagulation parameters in corona patients is associated with the severity of the disease and poor prognosis. ${ }^{14}$

The mean d-dimer values of the patients was $4.9 \pm 13.3$ $\mu \mathrm{g} / \mathrm{ml}$ in present study. Our findings are higher than Garcia-Olivé I et al, ${ }^{15}$ who reported Mean d-dimer levels as 1.16 on admission, and higher at $5.1 \mu \mathrm{g} / \mathrm{ml}$ in patients with suspicion of pulmonary embolism. We observed that the d-dimer readings, 162 (83.9\%) had d-dimer levels more than $0.5 \mu \mathrm{g} / \mathrm{ml}$. Zhou $\mathrm{F}$ et $\mathrm{al}^{13}$ reported from a multi-centered cohort study from the mainland China that a higher level of d-dimers more than $0.5 \mu \mathrm{g} / \mathrm{ml}$ shows the severity of the disease while the levels of d-dimers $>1 \mu \mathrm{g} / \mathrm{ml}$ at time of admission are associated with higher mortality in COVID-19.

In present study we noted a significant difference in the levels of d-dimers in age groups. In patients with age $>55 \mathrm{yr}$ the relative risk of higher values of $\mathrm{d}$ dimers above normal was $1.18(r r=1.18)$ without reaching a statistically significant $\mathrm{p}$-value $(p=0.47)$. Similarly Survival rate of patients with deranged ddimers drops to $30 \%$ in patients with age $\geq 80 \mathrm{yr}$ and $45 \%$ at age $\leq 70$ yr using Kaplan Meir test. Yao, Y et al. ${ }^{16}$ concluded that age $>60 \mathrm{yr}$ and high levels of $\mathrm{d}-$ dimers (more than $1 \mu \mathrm{g} / \mathrm{ml}$ ) can help clinicians to identify the patients at risk of worse outcome in term of death.

Another study published in JAMA, reported that it would be more beneficial to use the age adjusted cut off values of the d-dimers for the specific populations specially in the scenario of COVID-19 and must be added as part of the national surveillance system for detection of corona cases as mortality and severity of 
the disease increases with an increase in age of patients ${ }^{17}$ that matches our findings.

We further noted that the total deaths, 29/32 (91\%) were recorded in patients with d-dimers $>0.5 \mu \mathrm{g} / \mathrm{ml}$, with (15/32) $47 \%$ in patients with age $>55 \mathrm{yr}$ and ddimers $>0.5 \mu \mathrm{g} / \mathrm{ml}$.

The trial published in JAMA concluded that d-dimer levels of more than $2 \mu \mathrm{g} / \mathrm{ml}$ is the only trusted and reliable indicator/variable associated with increased odds (ten times higher probability) of case fatality in COVID-19 (OR $=10.7, \mathrm{p}=0.04) .{ }^{17} \mathrm{CDC}$ report from China showed $80 \%$ of the causalities (deaths) due to COVID-19 were in the adults aged > $60 \mathrm{yr}$ as compared to $0.1 \%$ in person aged < $19 \mathrm{yr} .{ }^{9}$ Similarly Italy is the second mostly affected country in the world, with more than 80000 cases of SARS-CoV infection. They reported a higher mortality in aged people as compared to younger population that identifies an immunity gap. ${ }^{18}$ An elevation of d-dimers indicates the activation of fibrinolytic process and is of diagnostic and prognostic values in COVID-19 patients. $^{19}$

\section{Conclusion}

We concluded that the deranged d-dimers levels were observed in $84 \%$ of the COVID-19 patients. Age $>55$ yr and female gender are at higher risk of deranged ddimers and further consequences. Survival rate of patients with deranged d-dimers drops to $30 \%$ in patients with age $>80 \mathrm{yr}$ and $45 \%$ at age $\leq 70 \mathrm{yr}$.

Therefore despite the difference in opinion of the scientist the present pooled analysis of the so for available data shows that a higher d-dimer level indicates a higher risk of mortality due to COVID-19. It is therefore suggested on the basis of the findings that an early advising d-dimer levels in COVID-19 patients which is a rapid test, non expensive, accessible and affordable, can be of significant help with better satisfaction of the clinicians working on the management of COVID-19 patients.

\section{Conflict of interest}

None declared by the authors

\section{Authors' contribution}

SK- Data Collection, conduct of Study, critical review, concept

HK- Data analysis, writing the manuscript, concept, critical review

SK- Data Collection, conduct of study

MA- Data analysis, manuscript writing

\section{References}

1. Guo YR, Cao QD, Hong ZS, Tan YY, Chen SD, Jin $\mathrm{HJ}$, et al. The origin, transmission and clinical therapies on corona virus disease 2019 (COVID-19) outbreak - an update on the status. Mil Med Res. 2020;7(1):11. [PubMed] DOI: 10.1186/s40779-020-00240-0

2. Munster VJ, Koopmans M, van Doremalen N, van Riel $D$, de Wit $E$. A novel coronavirus emerging in china - key . questions for impact assessment. $\mathrm{N}$ Engl J Med. 2020;382:692-694. [PubMed] DOI: 10.1056/NEJMp2000929

3. Azamfirei R. The 2019 novel coronavirus: a crown jewel of pandemics? J Crit Care Med (Targu Mures). 2020;6(1):3-4. [PubMed] DOI: 10.2478/jccm-2020$\underline{0013}$

4. Epidemiology Working Group for NCIP Epidemic Response, Chinese Center for Disease Control and Prevention. The epidemiological characteristics of an outbreak of 2019 novel coronavirus diseases (COVID19) in China. Zhonghua Liu Xing Bing Xue Za Zhi. 2020;41(2):145-151. [PubMed] DOI: 10.3760/cma.j.issn.0254-6450.2020.02.003

5. Driggin E, Madhavan MV, Bikdeli B, Chuich T, Laracy J, Biondi-Zoccai G, et al. Cardiovascular Considerations for Patients, Health Care Workers, and Health Systems During the COVID-19 Pandemic. J Am Coll Cardiol. 2020 May 12;75(18):2352-2371. [PubMed] DOI: 10.1016/.j.jacc.2020.03.031

6. Fan BE, Chong VCL, Chan SSW, Lim GH, Lim KGE,

Tan GB, et al. Hematologic parameters in patients with COVID-19 infection. Am J Hematol. 2020 Jun;95(6):E131-E134. [PubMed] DOI: 10.1002/ajh.25774

7. Zhou F, Yu T, Du R, Fan G, Liu Y, Liu Z, et al. Clinical course and risk factors for mortality of adult inpatients with COVID-19 in Wuhan, China: a retrospective cohort study. Lancet. 2020 Mar 28;395(10229):1054-1062. [PubMed] DOI: 10.1016/S0140-6736(20)30566-3

8. Tang N, Li D, Wang X, Sun Z. Abnormal coagulation 
parameters are associated with poor prognosis in patients with novel coronavirus pneumonia. J Thromb Haemost. 2020 Apr;18(4):844-847. [PubMed] DOI: 10.1111/jth. 14768

9. Zhang L, Yan X, Fan Q, Liu H, Liu X, Liu Z, et al. Ddimer levels on admission to predict in-hospital mortality in patients with Covid-19. J Thromb Haemost. 2020 Jun;18(6):1324-1329. [PubMed] DOI: 10.1111/jth.14859

10. Yu B, Li X, Chen J, Ouyang M, Zhang H, Zhao X, et al. Evaluation of variation in D-dimer levels among COVID19 and bacterial pneumonia: a retrospective analysis. J Thromb Thrombolysis. 2020;1-10. [PubMed] DOI: 10.1007/s11239-020-02171-y

11. Unicef UK. The United Nations Convention on the Rights of the Child. Unicef London: [cited January 13, 2019]. Available at https://www.unicef.org.uk/what-wedo/un-convention-child-rights/

12. Petry NM. A comparison of young, middle-aged, and older adult treatment-seeking pathological gamblers. Gerontologist 2002;42(1):92-99. [PubMed] DOI: 10.1093/geront/42.1.92

13. Zhou F, Yu T, Du R, Fan G, Liu Y, Liu Z, et al. Clinical study. Lancet. 2020 Mar 28;395(10229):1054-1062.

[PubMed] DOI: 10.1016/S0140-6736(20)30566-3

14. Marietta M, Coluccio V, Luppi M. COVID-19, coagulopathy and venous thromboembolism: more questions than answers. Intern Emerg Med. $2020 \mathrm{Jul}$ 11:1-13. [PubMed] DOI: $10.1007 / \mathrm{s} 11739-020-$ 02432-x

15. Garcia-Olivé I, Sintes H, Radua J, Abad Capa J, Rosell A. D-dimer in patients infected with COVID-19 and suspected pulmonary embolism. Respir Med. 2020 Aug;169:106023. [PubMed] DOI: 10.1016/j.rmed.2020.106023

16. Yao Y, Cao J, Wang Q, Shi Q, Liu K, Luo Z, et al. Ddimer as a biomarker for disease severity and mortality in COVID-19 patients: a case control study. J Intensive Care. 2020 Jul 10;8:49. [PubMed] DOI: 10.1186/s40560-020-00466-z

17. Onder G, Rezza G, Brusaferro S. Case-Fatality rate and characteristics of patients dying in relation to COVID-19 in Italy. JAMA. 2020 May 12;323(18):1775-1776. [PubMed] DOI: 10.1001/jama.2020.4683

18. CDC COVID-19 Response Team. Severe outcomes among patients with coronavirus disease 2019 (COVID19) - United States, February 12-March 16, 2020. MMWR Morb Mortal Wkly Rep. 2020 Mar 27;69(12):343-346. [PubMed] DOI: $\underline{10.15585 / \mathrm{mmwr} \cdot \mathrm{mm} 6912 \mathrm{e} 2}$

19. Lippi G, Favaloro EJ. D-dimer is Associated with Severity of Coronavirus Disease 2019: A Pooled Analysis. Thromb Haemost. 2020 May;120(5):876-878. [PubMed] DOI: $\underline{10.1055 / \mathrm{s}-0040-1709650}$ 